
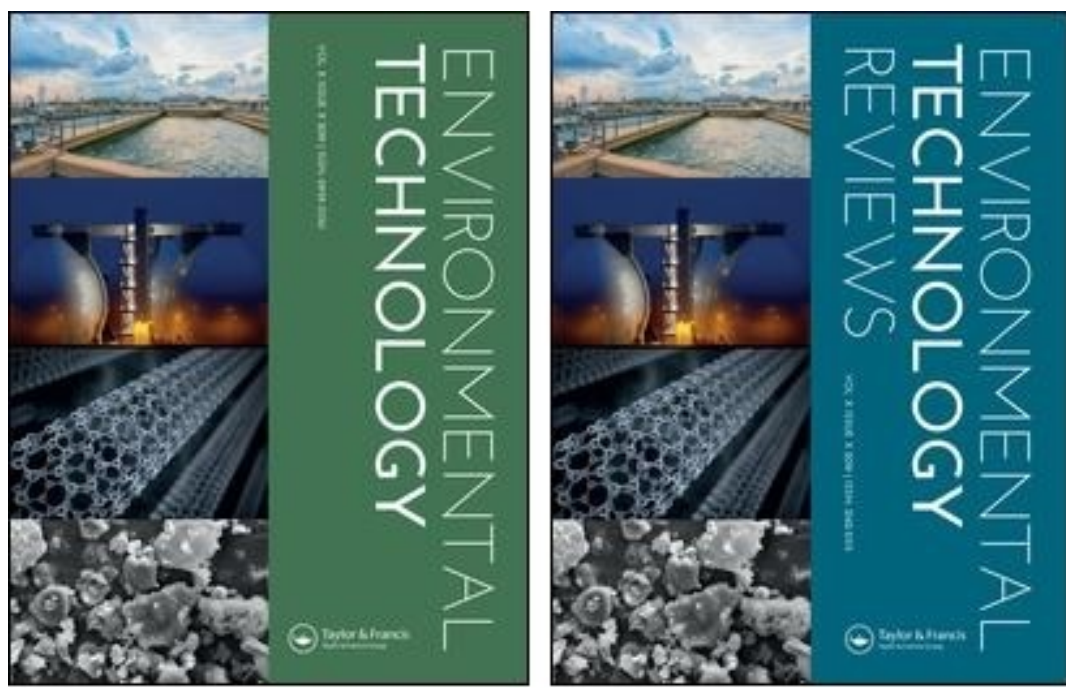

\title{
Biotransformation of chemically dispersed diesel at sub- zero temperatures using artificial brines
}

\begin{tabular}{|r|l|}
\hline Journal: & Environmental Technology \\
\hline Manuscript ID & Draft \\
\hline Manuscript Type: & Original Article \\
\hline Author: & $\mathrm{n} / \mathrm{a}$ \\
\hline Complete List of Authors: & $\begin{array}{l}\text { Dang, Nga; SINTEF Narvik AS, Cold Climate Technology } \\
\text { Petrich, Chris; SINTEF Narvik AS, Cold Climate Technology } \\
\text { O'Sadnick, Megan ; SINTEF Narvik AS, Cold Climate Technology } \\
\text { Torske , Lisa; Akvaplan-niva AS }\end{array}$ \\
\hline Keywords: & $\begin{array}{l}\text { Biotransformation, Biodegradation, dispersed diesel, sub-zero } \\
\text { temperature, dispersant }\end{array}$ \\
\hline &
\end{tabular}

\section{SCHOLARONE \\ Manuscripts}




\title{
Biotransformation of chemically dispersed diesel at sub-zero temperatures using artificial brines
}

\author{
Nga Phuong Dang ${ }^{a *}$, Chris Petrich $^{a}$, Megan O’Sadnick $^{a}$, Lisa Toske ${ }^{b}$ \\ ${ }^{*}$ a Department of Cold Climate Technology, SINTEF Narvik AS, N-8504 Narvik, Norway \\ bAkvaplan niva, N-9037 Tromsø, Norway; \\ Corresponding author: \\ Dr. Nga Phuong Dang \\ Department of Cold Climate Technology \\ SINTEF Narvik AS. \\ 8504 Narvik, Norway \\ Email:nga.dang@norut.no; \\ Tel: +4748190323
}




\title{
Biotransformation of chemically dispersed diesel at sub-zero temperatures using artificial brines
}

\author{
Nga Phuong Dang ${ }^{a *}$, Chris Petrich ${ }^{a}$, Megan O’Sadnick ${ }^{a}$, Lisa Toske ${ }^{b}$
}

\begin{abstract}
The biotransformation of hydrocarbon compounds in seawater at sub-zero temperature has gained research interest in recent years with the most focus placed on temperatures around $0{ }^{\circ} \mathrm{C}$. In this study, biotransformation of dispersed diesel at sub-zero temperatures $\left(-2\right.$ to and $\left.-6{ }^{\circ} \mathrm{C}\right)$ in artificial brines, prepared by adding Instant Ocean salt to natural seawater to increase salinity, is examined. The oil was pre-mixed with dispersant Finasol 51 to prepare the dispersed oil at $2 \mathrm{mg}$ $1^{-1}$. The native microorganisms in sub-arctic seawater were able to adapt to high salinity and lower temperature in the sea ice brine at -2 and $-6{ }^{\circ} \mathrm{C}$ and were capable of biotransforming hydrocarbon compounds. Complete depletion of low and middle-range molecular weight $n$ alkanes, $2 / 3$ ring-PAHs and their alkylated compounds was observed after 123 days at $-2{ }^{\circ} \mathrm{C}$. Similar depletion patterns were demonstrated at $-6^{\circ} \mathrm{C}$ but with a lower depletion level. This study suggests that: biodegradation will be intensive for dispersed diesel which floats at the icewater interface and reach the bottom part of sea ice which is usually at around $-2{ }^{\circ} \mathrm{C}$. However, for oil with high pour point, biodegradation process will be more affected by low temperature. Therefore, biodegradation rate should be established for each individual oil type.
\end{abstract}

Keywords: Biotransformation, biodegradation, dispersed diesel, sub-zero temperature, dispersant

\section{Introduction}

Sea ice is an ideal habitat for both psychrophilic and psychrotrophic microorganisms. Microbial activities have been measured at the temperatures closed to freezing point of water and in marine ice at temperature lower than $-10^{\circ} \mathrm{C}$, indicating that slow hydrocarbon biodegradation occurs in oil contaminated ice [1]. But very few studies have focused on biodegradation of oil in sea ice and how sea-ice microorganisms respond to the presence of oil [2, 3, 4, 5, 6, 7]. Gammaproteobacteria became the predominant phylotype in oil-contaminated sea ice from both Svalbard [2,3] and bottom sea ice from Canadian Arctic Archipelago [4] which included bacterial genera such as Marinobacter, Shewanelle, and Pseudomonas [2] and Colwellia, Marinomonas and Glaciecola [3].

How hydrocarbon compounds are biotransformed in sea ice was studied in more detail using melted sea ice held at a temperature of $-1.7^{\circ} \mathrm{C}[5]$ and with in situ sea ice at 1.3 to $-3.7^{\circ} \mathrm{C}[6]$. Alkanes showed the highest loss, followed by methylated-PAHs and PAHs in both sea ice and under-ice water, but to a lesser extent in sea ice [5]. Vergeynst observed that biodegradation of n-alkane occurred only in the under-ice seawater down to temperatures of $-1.3{ }^{\circ} \mathrm{C}$, but not in the ice at $-3.2^{\circ} \mathrm{C}[6]$. The study also revealed that photooxidation was the main process that contributed in the removal of PAHs in the ice and the upper layer of the water column, rather than the biodegradation process.

Biodegradation of dispersed oil at low temperatures has gained more interest recently due to the effectiveness of dispersant in removing oil slicks from the ocean surface even at low temperatures $[8,9,10,11]$. The lowest studied temperature was $-1{ }^{\circ} \mathrm{C}[8]$. We expect that the physical behaviour of dispersed oil in sea ice is similar to that of crude oil. Crude oil which floats at the ice-water interface can enter the skeletal layer of the ice where temperature is at 
around $-1.8^{\circ} \mathrm{C}$ and rise through sea ice channels and into the pore space if it is permeable enough (e.g. $>-4{ }^{\circ} \mathrm{C}$ ) [12]. It is however, unclear if biotransformation of dispersed oil could be substantial at temperatures below $-2{ }^{\circ} \mathrm{C}$ and what could be the rate-limiting factors of the biodegradation process. Therefore, in this study, we investigated the hydrocarbon biodegradation of chemically dispersed oil at both -6 and $-2{ }^{\circ} \mathrm{C}$.

\section{Materials and Methods Materials}

Surface seawater was collected from a beach at Kvitvika $\left(68.44208^{\circ} \mathrm{N} 17.38917^{\circ} \mathrm{E}\right)$, in Ofotfjord. Norway. The seawater was measured for salinity, $\mathrm{pH}$, temperature and nutrient level and used immediately after collecting. The seawater had salinity of $3.2 \pm 1 \%$, pH was $8 \pm 0.5$ and temperature $4 \pm 1{ }^{\circ} \mathrm{C}$.

The Class B Diesel fuel from Circle K was used for all experiments. The oil has viscosity 1.5$4.5 \mathrm{cSt}$ at $40{ }^{\circ} \mathrm{C}$, a density of $0.83 \mathrm{~g} / \mathrm{cm}^{3}$, and pour point of $-40{ }^{\circ} \mathrm{C}$.

Dispersant Finasol 51 (Total Special Fluids USA) was used for the experiments.

\section{Methods}

\section{Experiment setup}

To conduct the experiment at -2 and $-6{ }^{\circ} \mathrm{C}$, artificial brine was prepared from the collected seawater. The salinity of seawater brine at -2 and $-6{ }^{\circ} \mathrm{C}$ is expected to be 3.76 and $9.98 \%$ respectively [13], therefore Instant Ocean Salt (Aquarium Systems, France) was added to the seawater to achieve the respective salinities. The total amount of salt was divided and added to the seawater over 3 days under constant stirring at $4{ }^{\circ} \mathrm{C}$ to mitigate the effect of osmotic shock. The brines were then used for preparation of dispersed oil. $1000 \mathrm{mg}$ of diesel and $100 \mathrm{mg}$ of dispersant Finasol 51 were mixed and added to 51 of the brine solution. The mixture in a closed bottle, was then stirred at $400 \mathrm{rpm}, 4{ }^{\circ} \mathrm{C}$ for $24 \mathrm{~h}$. The artificial brines which contain dispersed oil were then diluted with clean brine solution to obtain the final oil concentration of $2 \mathrm{mg} / \mathrm{l}$. To avoid limitation of the nutrient, inorganic nutrients were supplemented to brine solution $\left(\mathrm{K}_{2} \mathrm{HPO}_{4} 12.6 ; \mathrm{KH}_{2} \mathrm{PO}_{4} 0.8 ; \mathrm{NaNO}_{3} 42 ; \mathrm{FeCl}_{3} 0.05 ; \mathrm{CaCl}_{2} 2.5 ; \mathrm{MgSO}_{4} 1.5 \mathrm{mg} / \mathrm{l}\right)$. Filteredsterile microcosms were prepared as with the dispersed oil microcosms, but the seawater was filtered using $0.2 \mu \mathrm{m}$ Sterivex filter SVGPL10RC (Merck Millipore) to remove the microorganisms before using for preparation of dispersed oil. In each microcosm, $150 \mathrm{ml}$ of the solution was filled in 500 ml-flask which were covered with PTFE-lined cap and incubated at $150 \mathrm{rpm}$ and at their respective temperatures. Two replicates were prepared for each setup. Monitoring of the incubation temperatures with temperature sensors showed that the temperatures of the microcosms in both experiments were $-1.5 \pm 0.5^{\circ} \mathrm{C}$ and $-5.5 \pm 0.5^{\circ} \mathrm{C}$.

\section{Oil analysis}

The seawater samples were extracted with dichloromethane (DCM) for measurement of semivolatile organic compound (SVOC) which includes C10-C36n-alkanes, two to four-ring PAHs and the oil biomarker compounds, trimethylphenanthrene (TMP) by gas chromatographymass spectrometry (GC-MS) and gas chromatography coupled to a flame ionization detector (GC-FID). The GC-MS was GC 7890, Agilent MS 5975C with automatic injector 7683, operated in ion-monitoring mode, using column Agilent HP-5ms Ultra Inert $(30 \mathrm{~m} \times 0.25 \mathrm{~mm}$ internal diameter, $0.25 \mu \mathrm{m}$ film thickness). The GC-FID was Agilent 7890A with a flame ionisation detector using a Varian WCOT Fused Silica column $(25 \mathrm{~m} \times 0.32 \mathrm{~mm}$ id, coating CPsil 8CD.CP7452). The SVOCs which included in the analyses are shown in Table S1. Depletions of SVOCs were recorded in the brine after normalization against the persistent biomarker TMP, commonly used in biodegradation studies [14]. The depletions were determined as percentages of normalised data at the start of the experiment (day 0 ) for each target oil compound. 
Enumeration of hydrocarbon-degrading bacteria

Numbers of viable hydrocarbon degraders were estimated by a modified most probable number (MPN) procedure in 96-well plates [15]. The wells were pre-filled with $180 \mu \mathrm{l}$ of Bushnell-Haas mineral medium which was supplemented with $3.76 \% \mathrm{NaCl}$ for both -2 and $-6{ }^{\circ} \mathrm{C}$ experiments, and $5 \mu \mathrm{l}$ filter-sterilized diesel B. After incubation in the dark at $10^{\circ} \mathrm{C}$ for 2 months, each well was inspected for dispersion of the oil and subsequently added $50 \mu$ filter-sterilized solution of the respiration indicator INT (2-(4-iodophenyl)-3(4-nitrophenyl)-5-phenyltetrazolium chloride, Sigma-Aldrich $\left(3 \mathrm{mg} \mathrm{ml}^{-1}\right)$. After over-night incubation in the dark at $20^{\circ} \mathrm{C}$, red and pink wells were counted as positive for growth.

\section{Results and discussions}

\section{Increase of hydrocarbon-degrading bacteria}

Enumeration of hydrocarbon-degrading bacteria (HDB) with MPN method showed a $10^{3}$-fold increase after 18 days exposed to the oil at $-2{ }^{\circ} \mathrm{C}$. HDB number was then decreased after 56 days (Fig. 1).

In the microcosms at $-6{ }^{\circ} \mathrm{C}$, the abundance of HDB increased $10^{2}$ folds gradually over 119 days compared to day 0 , suggesting a slower biodegradation process with potentially longer lag phase took placed at $-6^{\circ} \mathrm{C}$ than at $-2{ }^{\circ} \mathrm{C}$ (Fig 1). The HDB number became stable after 119 days. Increase in abundance of HDB is indirect evidence of oil biodegradation occurrence.

\section{Biotransformation of $\boldsymbol{n}$-alkanes}

Analysis of $n \mathrm{C} 10-n \mathrm{C} 36$ alkanes in the dispersed oil microcosms at $-2{ }^{\circ} \mathrm{C}$ showed significant depletion with time (Fig. 2A). About $83 \%$ depletion was observed in the dispersed oil microcosms after 123 days, while the sterile control microcosms only showed $36 \%$ depletion.

The degree of n-alkane $(n \mathrm{C} 10-n \mathrm{C} 36)$ depletion at $-6{ }^{\circ} \mathrm{C}$ was slightly lower compared to $-2{ }^{\circ} \mathrm{C}$, with $74 \%$ depletion observed after 123 days (Fig. 2B). The sterile microcosms also exhibited lower depletion compared to that at $-2{ }^{\circ} \mathrm{C}$, i.e., $18 \%$ only (Fig. 2B). Biotransformation clearly played a significant role in the depletion of the $n$-alkanes at tested temperatures.

The patterns of n-alkane depletion were shown in Fig. 3. Similar depletion trends were observed in the dispersed oil microcosms for both temperatures. The $n$-alkanes with carbon chain $n \mathrm{C} 10-$ $n \mathrm{C} 24$ were depleted the most, which coincided with the results of other studies at low temperature $[10,11,16]$.

Biodegradation of n-alkanes take place at the oil-seawater interface, as the microorganisms colonize and form a biofilm on the oil surface $[16,17]$. The process is influenced by the ambient temperature and chain length of n-alkanes. Reducing temperature will increase the oil viscosity, reduce diffusion of compound within the oil and induce wax precipitation [18], therefore reduce the bioavailability of the hydrocarbons. Degradation rate of n-alkanes decreases with increase of chain length at low temperature $[6,16]$. Extensive biotransformation of $n$-alkanes from oil has been demonstrated for seawater at low temperature from 0 to $-1.7^{\circ} \mathrm{C}$ but not lower $[5,6,8,16]$. Vergeynst observed biotransformation of $n$-alkanes in the under-ice seawater but not in sea ice at $-3.7^{\circ} \mathrm{C}$ and explained the obstruction of biofilm formation in the ice might be the cause [6]. With this study, we demonstrated that biotransformation of $n$-alkanes can also occur at lower temperature such as $-6^{\circ} \mathrm{C}$, but limited access to the $n$-alkanes such as obstruction of biofilm formation in sea ice or reduce of surface area when the oil becomes more viscous under effect of low temperature would be the rate limiting factors of $n$-alkane biodegradation. 


\section{Biotransformation of PAHs and alkylated hydrocarbons}

Decaline and 2-ring polyaromatic hydrocarbons (PAHs) depleted in both sterile control and dispersed oil microcosms at $-2{ }^{\circ} \mathrm{C}$ (Fig. 4A\&4B). The depletion however, was higher in the dispersed oil microcosms, 97 and 100\% depletion for decaline and 2-ring PAHs respectively. The 3-ring PAHs and dibenzothiophene (DBT) showed no depletion in the sterile control microcosms (Fig. 4A) but exhibited about $90 \%$ depletion in the dispersed oil microcosms (Fig. 4B). The 4-5 ring PAHs exhibited about $60 \%$ depletion in the dispersed oil microcosms (Fig 4B) and only about $29 \%$ in the sterile control microcosms (Fig 4A).

A similar trend was also observed for alkylated decalines and alkylated naphthalenes (Fig. 5A\&5B). Much higher depletion of these compounds occurred in the dispersed oil microcosms compared to the sterile control microcosms. However, no depletion was observed for alkylated bezothiophenes (BTs), alkylated fluorenes, alkylated 3-ring PAHs or alkylated DBTs in both type of microcosms. The significant difference between sterile control microcosms and dispersed oil microcosms suggested that PAHs, alkylated decalines and alkylated naphthalenes were biotransformed at $-2{ }^{\circ} \mathrm{C}$.

Again, the decaline showed depletion in both sterile control and dispersed oil microcosms at -6 ${ }^{\circ} \mathrm{C}$ (Fig. 4C\&4D). The 2 and 3-ring PAHs however, exhibited depletion only in the dispersed oil microcosms, 42 and 35\% (Fig. 4D). These depletions however are lower than those at $-2{ }^{\circ} \mathrm{C}$ Fig. 4B). Depletion of the $4 / 5$ ring PAHs was negligible at $-6^{\circ} \mathrm{C}$ (Fig. 4C\&4D).

Among alkylates hydrocarbons, only alkylated naphthalenes showed slightly higher depletion in the dispersed oil microcosms compared to that in the sterile microcosms (Fig. 5C\&5D). Depletion trends of PAHs and their alkyl substituted compounds are shown in Fig. 6 for both -2 and $-6{ }^{\circ} \mathrm{C}$. The depletion patterns were similar for both temperatures, but the degree of depletion was lower at $-6^{\circ} \mathrm{C}$. PAHs with alkyl substitution were depleted slower than their non-alkylated compounds, and the one with fewer alkyl substitution seemed to be depleted faster than the one with more substitutions $(\mathrm{C} 1>\mathrm{C} 2>\mathrm{C} 3>\mathrm{C} 4)$ (Fig. 6A). This is in agreement with other studies of chemically dispersed oil at $-1{ }^{\circ} \mathrm{C}[8]$ and $4-8{ }^{\circ} \mathrm{C}[9,10,19]$.

In our case, the depletion of 2/3 ring-PAHs was more affected by the temperature decrease (90$100 \%$ depletion at $-2{ }^{\circ} \mathrm{C}$, reduced to $35-42 \%$ depletion at $-6^{\circ} \mathrm{C}$ ) than the depletion of $n$-alkanes ( $83 \%$ depletion at $-2{ }^{\circ} \mathrm{C}$ reduced to $74 \%$ depletion at $-6{ }^{\circ} \mathrm{C}$ ). For both n-alkanes and nonalkylated $2 / 3$ ring-PAHs, the microbial biotransformation rates would reduce when the temperature decreased from -2 to $-6^{\circ} \mathrm{C}$. Naphthalene and non-alkylated $2 / 3$ ring-PAHs usually dissolute quickly from the oil drops, therefore their biotransformation mainly occurs with dissolved compounds. But for $n$-alkanes, their biotransformation occurs at the interface between oil and water by formation of biofilm on the oil surface [17]. This oil/water surface area properly would not change much at -2 and $-6{ }^{\circ} \mathrm{C}$ since the oil was still in liquid form, while the dissolution of PAHs would depend very much on temperature. However, for oil with high pour point, the influence of reduced temperature on biodegradation of $n$-alkanes and water-soluble hydrocarbons may be different from our result.

\section{Conclusion}

The native microorganisms in sub-arctic seawater were able to adapt to high salinity and lower temperature in the sea ice brine at -2 and $-6^{\circ} \mathrm{C}$, and biotransformed dispersed diesel 
extensively. Biotransformation played significant role in the depletion of $n$-alkanes, PAHs as well as the alkylated hydrocarbons at the tested temperatures. The pattern of hydrocarbon depletion at $-6{ }^{\circ} \mathrm{C}$ was not different from that at $-2{ }^{\circ} \mathrm{C}$, but the depletion extent was lower. Based on temperature and salinity, this study suggests that: i) biodegradation will be substantial for dispersed diesel which floats at the ice-water interface; ii) for dispersed diesel which percolates into sea ice channels or get incorporated into growing sea ice, biodegradation of low and middle-range PAHs will occur but properly become negligible as the ice temperature lower than $-6{ }^{\circ} \mathrm{C}$. Regarding n-alkanes, their biodegradation can be substantial at low temperature as demonstrated in this study, however, biofilm formation could be inhibited in sea ice, and the oilwater contact area can be limited as the oil becomes more viscous at low temperature, limiting biodegradation process of n-alkanes. Oil with high pour point is more affected by low temperature, therefore to predict the fate of dispersed oil in low temperature seawater, biodegradation rate should be established for each individual oil type.

\section{Acknowledgment}

The work was supported by the Regional Research Fund Nord Norge (RFFNORD), Norway, grant number 284681. We would like to sincerely thank Tore Pettersen for helping with the seawater sampling.

\section{References}

1. R. Margesin R and G. Feller, Biotechnological applications of psychrophiles, Environ. Echnol. 31 (2010), pp. 835-844.

2. B. Gerdes, R. Brinkmeyer, G. Dieckmann and E. Helmke, Influence of crude oil on changes of bacterial communities in Arctic sea-ice, FEMS Microbiol. Ecol. 53 (2005), pp. 129-139.

3. O.G. Brakstad, I. Nonstad, L.G. Faksness, P.J. Brandvik, Responses of Microbial Communities in Arctic Sea Ice after Contamination by Crude Petroleum Oil, Microb. Ecol. 55 (2008), pp. 540-552.

4. C.W. Greer, J. Wyglinski, C. Michel, N. Fortin, S. Sanschagrin, A. Niemi, L.G. Whyte, T.L. King, K. Lee, and E. Yergeau, Natural attenuation potential for oil in ice in Canadian Arctic marine environment, in Proceedings of the $37^{\text {th }}$ AMOP Technical Seminar on Environmental Contamination and Response, Environment Canada, Alberta, AB, 2014, pp. 666-681.

5. M.E. Garneau, C. Michel, G. Meisterhans, N. Fortin, T.L. King, C.W. Greer, and K. Lee, Hydrocarbon biodegradation by Arctic sea-ice and sub-ice microbial communities during microcosm experiments, Northwest Passage (Nunavut, Canada), FEMS Microbiol. Ecol. 92 (2016), fiw130. Available at https://doi.org/10.1093/femsec/fiw130.

6. L. Vergeynst, J.H. Christensen, K.U. Kjeldsen, L. Meire, W. Boone, L.M.V. Malmquist, and S. Rysgaard, In situ biodegradation, photooxidation and dissolution of petroleum compounds in Arctic seawater and sea ice, Water Res.148 (2019), pp. 459468.

7. N.P. Dang, N.P. Willassen, M.E. O'Sadnick, and C. Petrich C, Effect of Oil Pollution and Ice Formation on Microbial Community of Seawater from Ofotfjorden, Norway, In Proceedings of the $41^{\text {st }}$ AMOP Technical Seminar on Environmental Contamination and Response, Environment Canada, Ottawa, ON, Canada, 2018, pp. 546-558.

8. K.M. McFarlin, R.C. Prince, R. Perkins, and M.B. Leigh, Biodegradation of dispersed oil in Arctic seawater at $-1^{\circ} \mathrm{C}$, PLoS One 9 (2014), e84297. 
9. O.G. Brakstad, T. Nordtug, and M. Throne-Holst, Biodegradation of dispersed Macondo oil in seawater at low temperature and different oil droplet sizes, Mar. Pollut. Bull. 93 (2015), pp. 144-152.

10. O.G. Brakstad, E.J. Davies, D. Ribicic, A. Winkler, U. Bronner, and R. Netzer, Biodegradation of dispersed oil in natural seawaters from Western Greenland and a Norwegian fjord. Polar. Biol. 41 (2018), pp. 2435-2450.

11. D. Ribicic, R. Netzer, A. Winkler, and O.G. Brakstad, Microbial communities in seawater from an Arctic and a temperate Norwegian fjord and their potentials for biodegradation of chemically dispersed oil at low seawater temperatures, Mar. Pollut. Bull. 129 (2018), pp. 308-317.

12. NORCOR, The interaction of crude oil with Arctic sea ice. Beaufort Sea Technical Report, No. 27, Beaufort Sea Project, Department of the Environment, Victoria, BC, Canada, 1975.

13. G.F.N. Cox, and W.F Weeks, Equations for determining the gas and brine volumes in sea ice samples. J. Glaciol. 29 (1983), pp. 306-316.

14. G.S. Douglas, K.J. McCarthy, D.T. Dahlen, J.A. Seavey, W. G. Steinhauer, R. C. Prince, and D. L. Elmendorft, The use of hydrocarbon analyses for environmental assessment and remediation. J. Soil Contam. 1 (1992), pp. 197-216.

15. S. Røberg, S.K. Stormo, and B. Landfald, Persistence and biodegradation of kerosene in high-arctic intertidal sediment, Mar. Environ. Res. 64 (2007), pp. 417-428.

16. S. Lofthus, R. Netzer, A.S. Lewin, T.M.B. Heggeset, T. Haugen, and O.G. Brakstad, Biodegradation of n-alkanes on oil-seawater interfaces at different temperatures and microbial communities associated with the degradation. Biodegradation 29 (2018), pp. 141-157.

17. O.G. Brakstad, K. Bonaunet, T. Nordtug, and Ø. Johansen, Biotransformation and dissolution of petroleum hydrocarbons in natural flowing seawater at low temperature. Biodegradation 15 (2004), pp. 337-346.

18. P.J. Brandvik, and L.G. Faksness, Weathering processes in Arctic oil spills: meso-scale experiments with different ice conditions, Cold Reg. Sci. Technol. 55 (2009), pp. 160166.

19. R.C. Prince, K.M. McFarlin, J.D. Butler, E.J. Febbo, F.C.Y. Wang, and T.J. Nedwed, The primary biodegradation of dispersed crude oil in the sea, Chemosphere 90 (2013), pp. 521-526. 
Table S1. Aromatic hydrocarbon target groups from GC-MS analyses of semivolatile organic compounds include in this study

\begin{tabular}{c|l}
\hline Group & \multicolumn{1}{c}{ Compounds } \\
\hline Naphthalenes & $\begin{array}{l}\text { Naphthalene, C1-naphthalenes, C2-naphthalenes, C3-naphthalenes, C4- } \\
\text { naphthalenes } \\
\text { Benzo(b)thiophene, C1-benzo(b)thiophenes, C2-benzo(b)thiophenes, C3- } \\
\text { benzo(b)thiophenes, C4-benzo(b)thiophenes, biphenyl, acenaphthylene, } \\
\text { acenaphthene, dibenzofuran, fluorene, C1-fluorenes, C2-fluorenes, C3- } \\
\text { fluorenes, phenanthrene, anthracene, C1-phenanthrene/anthracenes, C2- } \\
\text { phenanthrene/anthracenes, C3-phenanthrene/anthracenes, C4- } \\
\text { phenanthrene/anthracenes, dibenzothiophene, C1-dibenzothiophenes, C2- } \\
\text { dibenzothiophenes, C3- dibenzothiophenes, C4-dibenzothiophenes } \\
\text { 2 to 3-ring } \\
\text { PAH/DBT } \\
\text { Fluoranthene, pyrene, C1-fluoranthenes/pyrenes, C2- } \\
\text { fluoranthenes/pyrenes, C3-fluoranthenes/pyrenes, chrysene, C1- } \\
\text { chrysenes, C2- chrysenes, C3- chrysenes, C4-chrysenes }\end{array}$ \\
\hline
\end{tabular}

Fig. 1 Abundance of hydrocarbon-degrading bacteria in the oil-spiked microcosms at $-2{ }^{\circ} \mathrm{C}$ for 123 days and at $-6{ }^{\circ} \mathrm{C}$ for 168 days. Data are shown as average value of two replicates.

Fig. 2 Percentage concentrations of n-alkanes (C10-C36) compared to day $0(100 \%)$ in sterile control and dispersed diesel microcosms which were incubated at $-2{ }^{\circ} \mathrm{C}(\mathrm{A})$ and $-6{ }^{\circ} \mathrm{C}(\mathrm{B})$. Data are shown as average value of two replicates.

Fig. 3 Peak height of individual $n$-alkane in microcosms with dispersed diesel which was incubated at $-2{ }^{\circ} \mathrm{C}$ (A) and $-6^{\circ} \mathrm{C}$ (B) at day 0 , day 56 and day 123 (The peak height of each $n$ alkane was normalized against TMP). Data are shown as average value of two replicates.

Fig. 4 Percentage concentrations of decaline and PAHs compared to day $0(100 \%)$ in sterile control microcosms $(\mathrm{A} \& \mathrm{C})$ and dispersed diesel microcosms $(\mathrm{B} \& \mathrm{D})$ which was incubated at -2 ${ }^{\circ} \mathrm{C}(\mathrm{A} \& \mathrm{~B})$ and $-6{ }^{\circ} \mathrm{C}(\mathrm{C} \& \mathrm{D})$. Data are shown as average value of two replicates.

Fig. 5 Percentage concentrations of alkylated hydrocarbons compared to day $0(100 \%)$ in sterile control microcosms (A\&C) and dispersed diesel microcosms (B\&D) which was incubated at -2 ${ }^{\circ} \mathrm{C}(\mathrm{A} \& \mathrm{~B})$ and $-6{ }^{\circ} \mathrm{C}(\mathrm{C} \& \mathrm{D})$. Data are shown as average value of two replicates.

Fig. 6 Percentage concentration of PAHs and methylated PAHs compared to day 0 in microcosms with dispersed diesel which was incubated at $-2{ }^{\circ} \mathrm{C}(\mathrm{A})$ and $-6{ }^{\circ} \mathrm{C}(\mathrm{B})$ (The depletions of the hydrocarbon compounds were determined after normalizing the targeted hydrocarbons against TMP and comparing with day 0 of 100\%). Data are shown as average value of two replicates. 


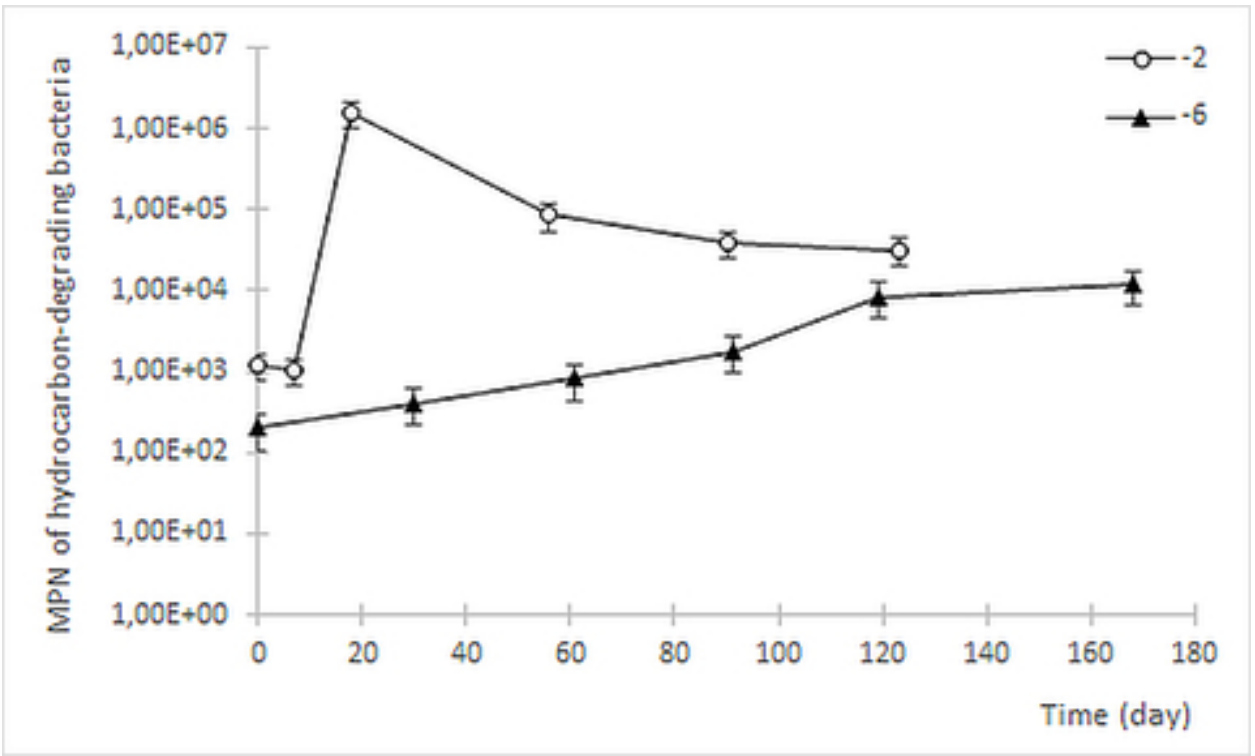

Fig. 1 Abundance of hydrocarbon-degrading bacteria in the oil-spiked microcosms at $-2{ }^{\circ} \mathrm{C}$ for 123 days and at $-6^{\circ} \mathrm{C}$ for 168 days. Data are shown as average value of two replicates.

$20 \times 12 \mathrm{~mm}(600 \times 600 \mathrm{DPI})$ 


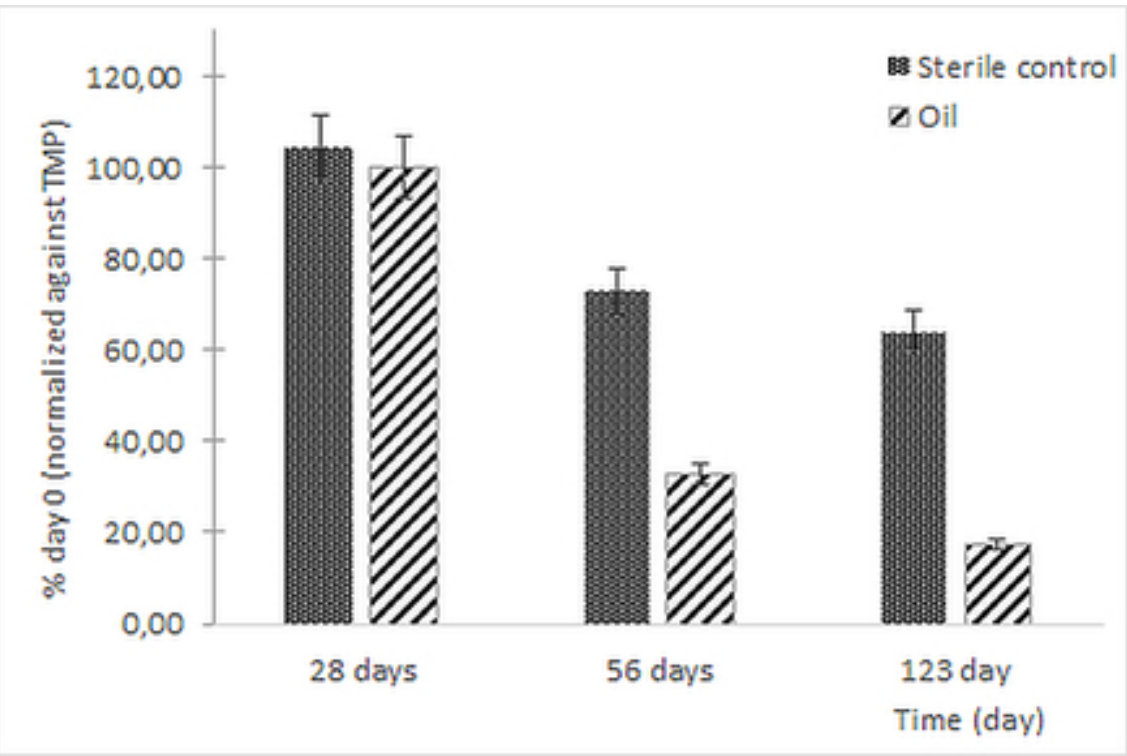

Fig. 2A Percentage concentrations of $n$-alkanes (C10-C36) compared to day $0(100 \%)$ in sterile control and dispersed diesel microcosms which were incubated at $-2{ }^{\circ} \mathrm{C}(\mathrm{A})$ and $-6^{\circ} \mathrm{C}(\mathrm{B})$. Data are shown as average value of two replicates.

$18 \times 12 \mathrm{~mm}(600 \times 600 \mathrm{DPI})$ 
Fig. 3A Peak height of individual n-alkane in microcosms with dispersed diesel which was in-cubated at $-2{ }^{\circ} \mathrm{C}$ (A) and $-6{ }^{\circ} \mathrm{C}(\mathrm{B})$ at day 0 , day 56 and day 123 (The peak height of each n-alkane was normalized against TMP). Data are shown as average value of two replicates.

$$
25 \times 18 \mathrm{~mm}(600 \times 600 \mathrm{DPI})
$$


Fig. 3B Peak height of individual n-alkane in microcosms with dispersed diesel which was in-cubated at $-2{ }^{\circ} \mathrm{C}$ (A) and $-6^{\circ} \mathrm{C}(\mathrm{B})$ at day 0 , day 56 and day 123 (The peak height of each $n$-alkane was normalized against TMP). Data are shown as average value of two replicates.

\section{$22 \times 16 \mathrm{~mm}(600 \times 600 \mathrm{DPI})$}




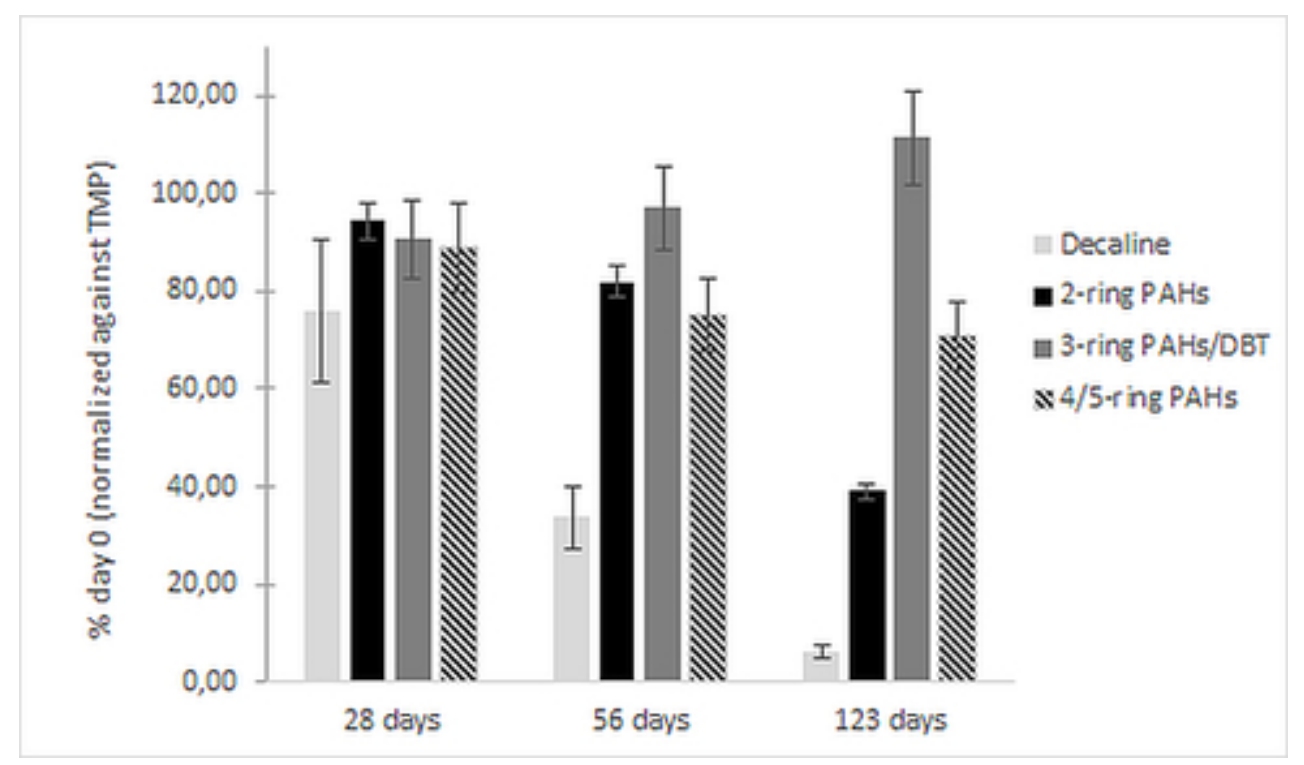

Fig. 4A Percentage concentrations of decaline and PAHs compared to day $0(100 \%)$ in sterile control microcosms (A\&C) and dispersed diesel microcosms (B\&D) which was incubated at $-2{ }^{\circ} \mathrm{C}(\mathrm{A} \& \mathrm{~B})$ and $-6{ }^{\circ} \mathrm{C}$ $(C \& D)$. Data are shown as average value of two replicates.

\section{$20 \times 12 \mathrm{~mm}(600 \times 600 \mathrm{DPI})$}


Fig. 4C Percentage concentrations of decaline and PAHs compared to day $0(100 \%)$ in sterile control microcosms $(A \& C)$ and dispersed diesel microcosms (B\&D) which was incubated at $-2{ }^{\circ} \mathrm{C}(A \& B)$ and $-6{ }^{\circ} \mathrm{C}$ (C\&D). Data are shown as average value of two replicates.

$$
19 \times 12 \mathrm{~mm}(600 \times 600 \mathrm{DPI})
$$


Fig. 4D Percentage concentrations of decaline and PAHs compared to day $0(100 \%)$ in sterile control microcosms (A\&C) and dispersed diesel microcosms (B\&D) which was incubated at $-2{ }^{\circ} \mathrm{C}(A \& B)$ and $-6^{\circ} \mathrm{C}$ $(C \& D)$. Data are shown as average value of two replicates.

$$
19 \times 12 \mathrm{~mm}(600 \times 600 \mathrm{DPI})
$$


Fig. 5A Percentage concentrations of alkylated hydrocarbons compared to day $0(100 \%)$ in ster-ile control microcosms (A\&C) and dispersed diesel microcosms (B\&D) which was incubated at $-2^{\circ} \mathrm{C}(\mathrm{A} \& \mathrm{~B})$ and $-6{ }^{\circ} \mathrm{C}$ $(C \& D)$. Data are shown as average value of two replicates.

\section{$26 \times 14 \mathrm{~mm}(600 \times 600 \mathrm{DPI})$}




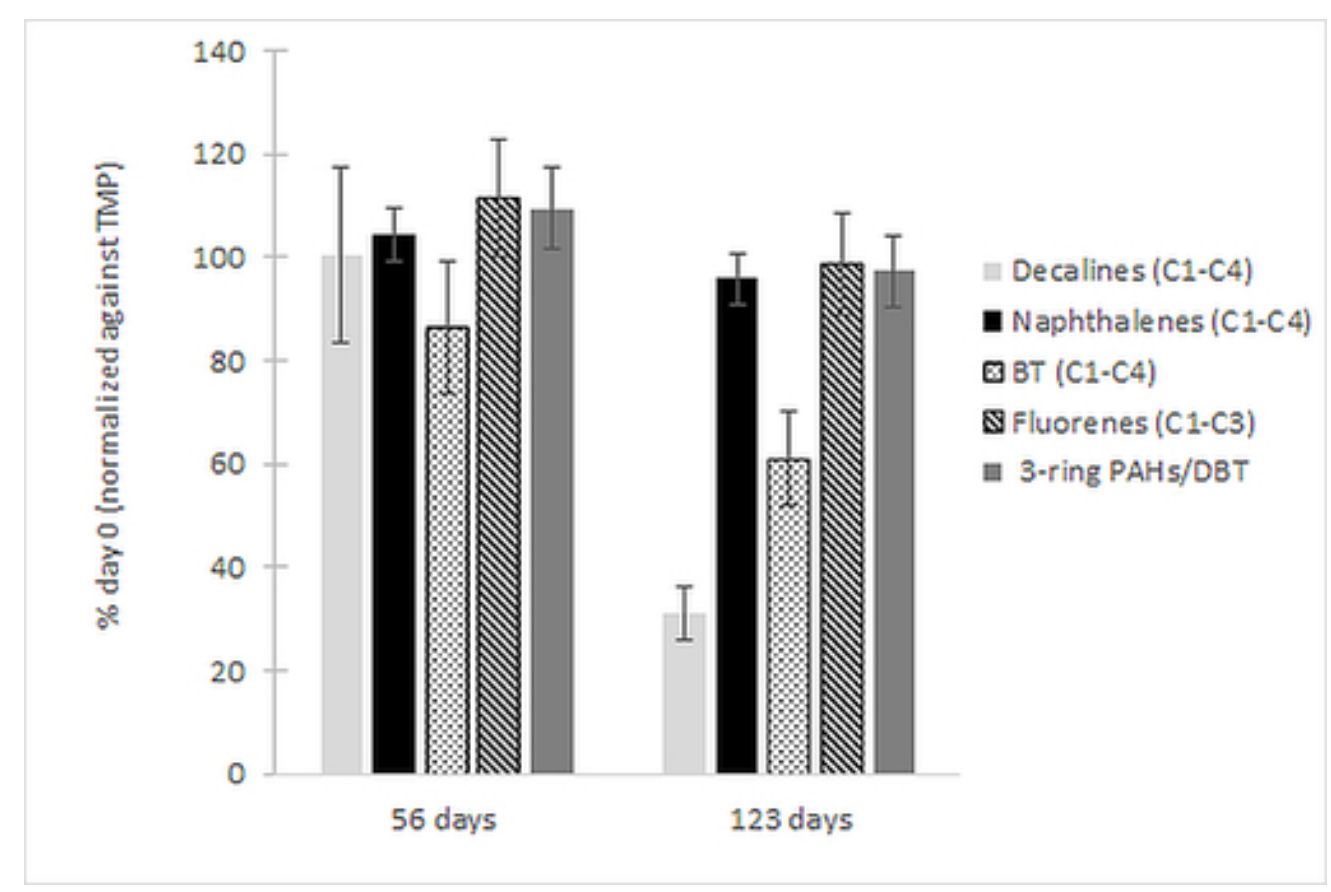

Fig. 5C Percentage concentrations of alkylated hydrocarbons compared to day $0(100 \%)$ in ster-ile control microcosms (A\&C) and dispersed diesel microcosms (B\&D) which was incubated at $-2{ }^{\circ} \mathrm{C}(\mathrm{A} \& \mathrm{~B})$ and $-6{ }^{\circ} \mathrm{C}$ $(C \& D)$. Data are shown as average value of two replicates.

\section{$21 \times 14 \mathrm{~mm}(600 \times 600 \mathrm{DPI})$}




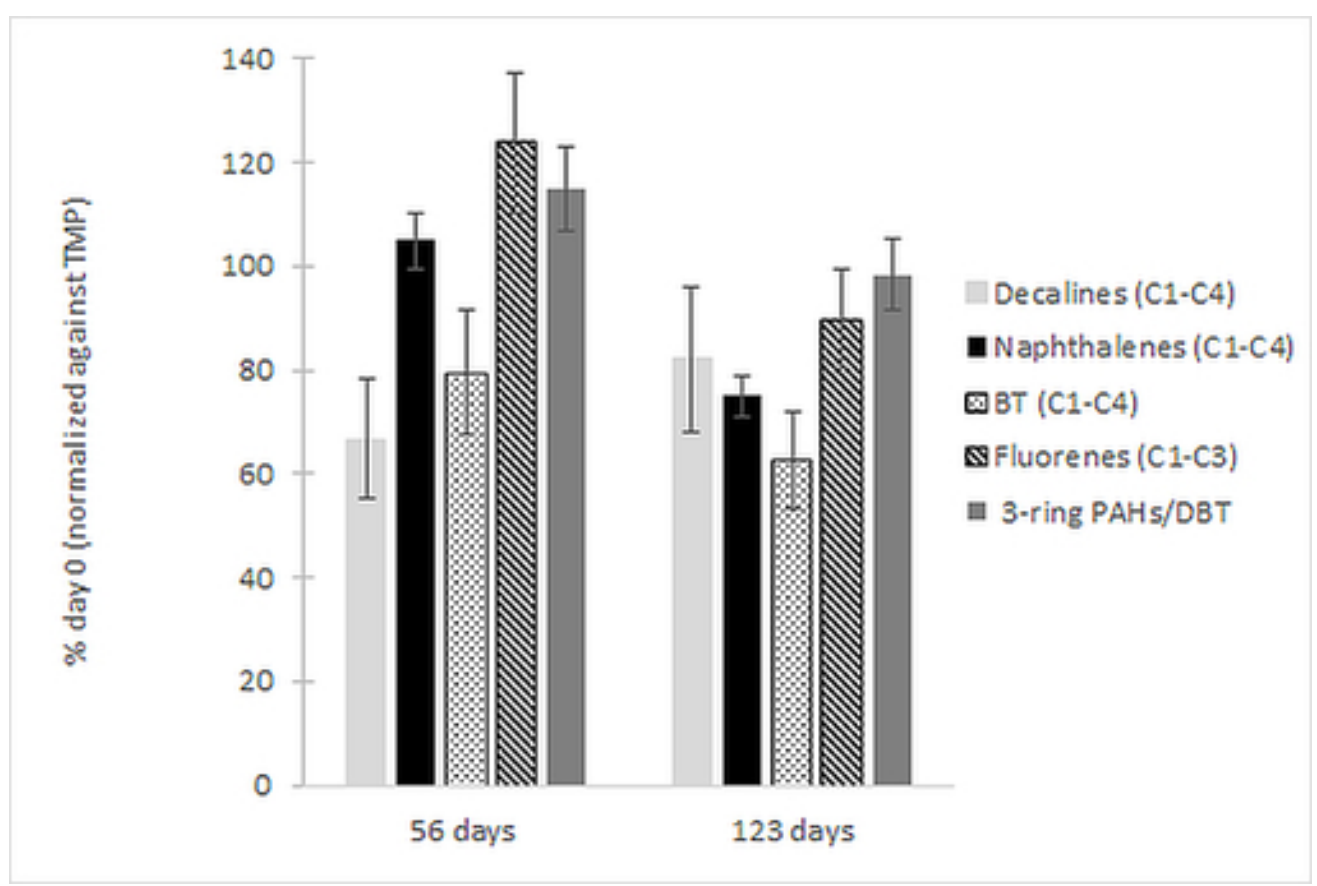

Fig. 5D Percentage concentrations of alkylated hydrocarbons compared to day $0(100 \%)$ in ster-ile control microcosms $(A \& C)$ and dispersed diesel microcosms $(B \& D)$ which was incubated at $-2{ }^{\circ} \mathrm{C}(A \& B)$ and $-6{ }^{\circ} \mathrm{C}$ (C\&D). Data are shown as average value of two replicates.

\section{$21 \times 14 \mathrm{~mm}(600 \times 600 \mathrm{DPI})$}




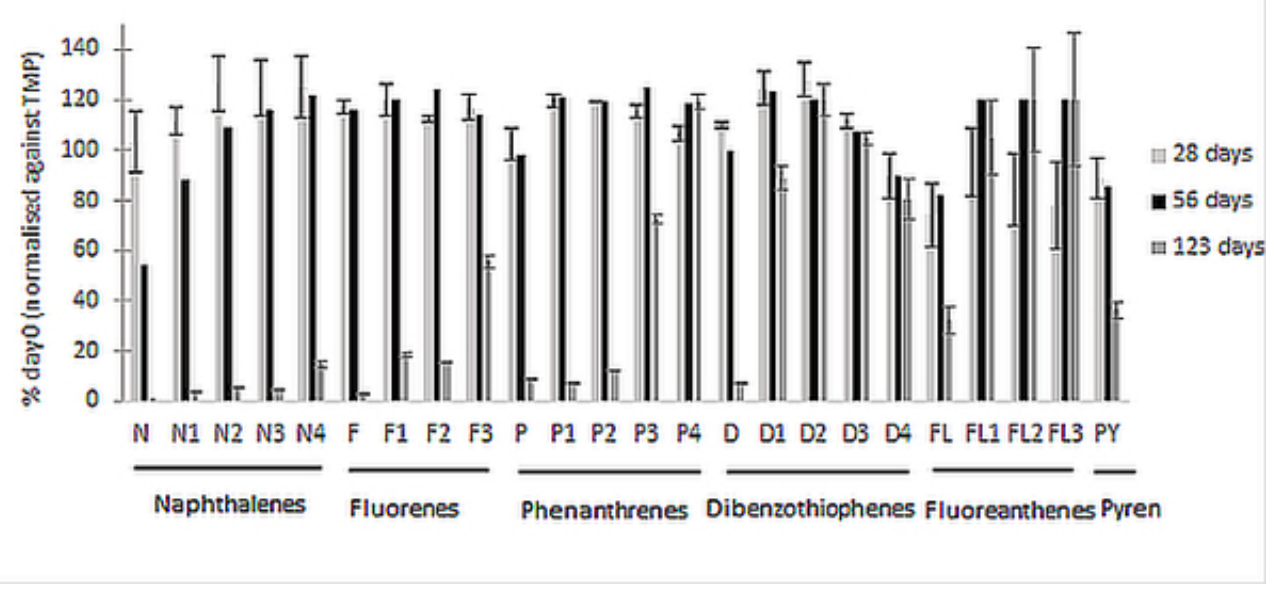

Fig. 6A Percentage concentration of PAHs and methylated PAHs compared to day 0 in micro-cosms with dispersed diesel which was incubated at $-2{ }^{\circ} \mathrm{C}(\mathrm{A})$ and $-6^{\circ} \mathrm{C}(\mathrm{B})$ (The depletions of the hydrocarbon compounds were determined after normalizing the targeted hydrocarbons against TMP and comparing with day 0 of $100 \%)$. Data are shown as average value of two replicates.

$25 \times 11 \mathrm{~mm}(600 \times 600 \mathrm{DPI})$ 